\title{
Rita Levi-Montalcini, one of the most prominent Italian personalities of the twentieth century
}

\author{
Antonio Federico
}

Published online: 25 January 2013

(C) Springer-Verlag Italia 2013

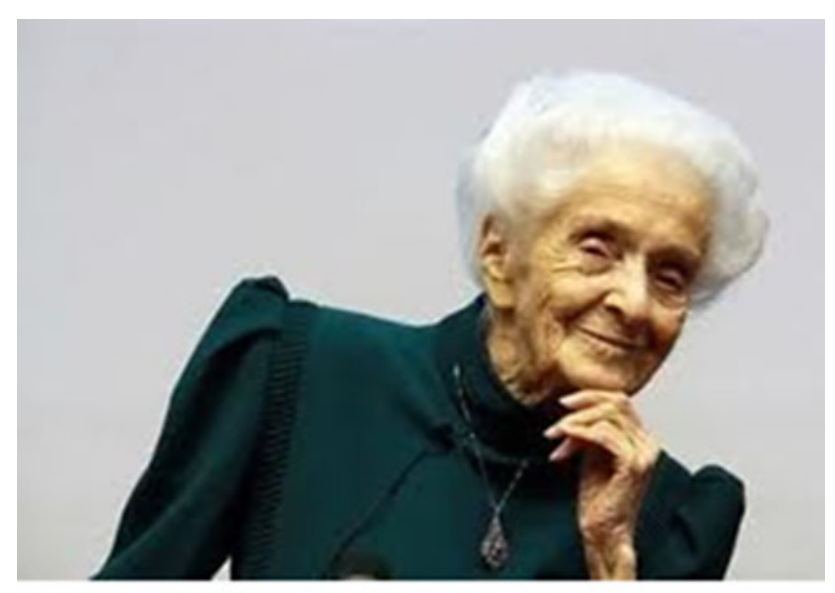

Thank you, Rita!

This was the sentence pronounced by a great number of people on the 2nd January 2013, during the funeral of Rita Levi-Montalcini, in the Monumental Cemetery in Turin, interpreting the opinion of all people in Italy, in Europe and in the World. And in the same way, the Journal Neurological Sciences wants to celebrate and remember her.

In fact she was an outstanding personality, that signed our history along all the twentieth century, and after her death at the age of 103, she leaves a memory of symbols to which we have to look as example of life and of high human principles. In fact her humanitarian and scientific activity for all the long life is a special heritage that we have to store in our memory and to transfer to young generations.

\footnotetext{
A. Federico $(\bowtie)$

Department of Medicine, Surgery and Neurosciences,

Medical School, University of Siena,

Viale Bracci 2, 53100 Siena, Italy

e-mail: federico@unisi.it
}

Born on 22 April 1909 at Turin from an Italian Jewish family, together with her twin sister Paola, she was the youngest of four children. Her parents were Adamo Levi, an electrical engineer and Adele Montalcini, an artist. Adamo discouraged his three daughters from attending college, since he was convinced that professional works will give limitations on their lives as wives and mothers. In spite of this, she decided to become a doctor. Remembering when she told to the father her decision, "He listened, looking at me with that serious and penetrating gaze of his that caused me such trepidation," she wrote in her autobiography, "Elogio dell'Imperfezione" (1988). But he also agreed to support her. Rita attended the University of Turin Medical School. During the medical studies, Giuseppe Levi, Professor of Anatomy and Histology, introduced her to the research on developing nervous system. She graduated summa cum laude, and became familiar with two fellow students in the laboratory of Prof. Levi, Renato Dulbecco and Salvador Luria, both of whom were later honored with Nobel Prizes. After graduating in 1936, she worked as Giuseppe Levi's assistant, and received a specialization in Clinica delle Malattie Nervose e Mentali. Her academic career was stopped by Benito Mussolini's 1938 Manifesto of Race and by the introduction of laws that did not allowed Jews to attend academic and professional careers.

During the Second World War, Rita Levi-Montalcini conducted experiments from a home laboratory, studying the growth of nerve fibers in chicken embryos, which were the basis of her later research.

As Rita says in her book entitled The Saga of the Nerve Growth Factor "the first attempts to obtain some knowledge of the control mechanisms of the nervous system date back to the beginning of the century.... In 1934, Viktor Hamburger (a student of Hans Spemann) explored the 
effect of limb bud extirpation, in 3-day-old chick embryos, on spinal cord motor neurons in charge of the limb". The consequence was that the corresponding motor nerve cells, in the absence of their territories of innervation, failed to grow and differentiate. The author, therefore, hypothesized that under normal conditions "the pioneer nerve fibers, after reaching their target limb tissues, send signals to their centers which at this stage consist mainly of still undifferentiated nerve cells. Upon receiving the signal, they would be induced to undergo differentiation".

A few years later, Rita Levi-Montalcini in Turin focused her attention on the sensory neurons of the dorsal root ganglia and concluded that their failure to establish synaptic contacts with their end organs was responsible for the massive death of these cells.

For the racial laws, Rita's first results that could not be presented and published in Italy were published in the Belgian Archives de Biologie, and afterward they were sent to the Pontificia Academia Scientiarum, which did not discriminate racially. Rita in 1939 spent a year at the Institut Neurologique in Brussels. The Nazi invasion of Belgium prompted her to return to Italy in December of the same year. In Turin, in a small laboratory in a room of her house, she continued her work in collaboration with her mentor, Giuseppe Levi.

In 1943, the Levi-Montalcini family moved to Florence, and also here Rita set up a home laboratory. Her family returned to Turin in 1945.

"In Florence I was in daily contact with many close, dear friends and courageous partisans of the "Partito di Azione". In August of 1944, the advancing Anglo-American armies forced the German invaders to leave Florence. At the AngloAmerican Headquarters, I was hired as a medical doctor and assigned to a camp of war refugees who were brought to Florence by the hundreds from the North where the war was still raging. Epidemics of infectious diseases and of abdominal typhus spread death among the refugees, where I was in charge as nurse and medical doctor, sharing with them their suffering and the daily danger of death." [1].

In September 1946, Rita Levi-Montalcini accepted an invitation to Washington University in St. Louis, Missouri, under the supervision of Professor Viktor Hamburger, Chairman of the Department of Zoology, to reinvestigate together with him the effects of limb bud ablation on its innervating nerve cells. Although the initial invitation was for one semester, she remained there for 30 years. It was there that she did her most important work isolating the nerve growth factor (NGF) from observations of certain cancer tissues that cause extremely rapid growth of nerve cells in 1952. In St. Louis University, she was associate professor in 1956 and full professor in 1958.

Between 1956 and 1958, two other most powerful sources of NGF were discovered in snake venom and in adult male mouse submaxillary salivary glands. The main target tissues were identified as neural crest derivatives. She isolated and characterized the NGF, in collaboration with a biochemist, Dr. S. Cohen: they described the functions on the cell proliferation and differentiation of this factor, that was the first growth factor characterized and that afterward will be considered a pleiotropic molecule, present in many tissues including cholinergic neurons, mastocytes, immunitary cells, neuroendocrine cells, keratocytes, etc. [2-6].

In 1962, she helped establish the Institute of Cell Biology in Rome and became its first director. In 1968 Rita Levi-Montalcini came back to Italy and established a center of research on NGF under the sponsorship of the Italian National Research Council. She retired from Washington University in 1977, becoming a guest professor and splitting her time between Rome and St. Louis. In 1990, the modulatory role of NGF in homeostatic processes in the neuroendocrine-immune triad was discovered and became the object of intense investigation.

From 1983 to 1986, she was President of the Italian Association for Multiple Sclerosis and after she was Honorary President, showing a great interest for the problems of patients with this and other neurodegenerative disorders.

In 1986, she received a Nobel Prize for Medicine with his collaborator, Prof. S. Cohen, for their research on NGF, that as reported by the Nobel Committee, "is a fascinating example how an argute observer may extrapolate useful hypothesis from an apparent caos".

Rita Levi-Montalcini founded the European Brain Research Institute in 2002 in Rome, and then served as its president.

In an interview with Rita by G. Giudice, to the answers regarding the consequences of her discovery for Developmental Biology and about its applications, she told that "The discovery of NGF has demonstrated that the protein factors which are released by all the cells in an organism play an essential role in the development of every system (in the case of my factor, the nervous system)." And that "NGF has found unhoped-for possibilities of clinical application to the most varied pathological conditions of a degenerative nature and to those belonging to homeodynarnic systems (nervous, immune and endocrine). A recent discovery has been that NGF may play an important role in Alzheimer's disease, in disorders of viral origin such as immune deficiency disorder (the HIV virus), and in afflictions of an autoimmune nature (multiple sclerosis). One clinical application with great potential for development-which has recently been discovered by some young researchers working in my own group and in a team at the Venice Eye Clinic-is the use of NGF as a collyrium with which to treat lesions of the cornea (of either traumatic, 
viral or toxic origin) that inevitably cause the cornea's destruction and, therefore, blindness. If administered topically, NGF induces the permanent regeneration of the damaged cornea and its total functional repair." [6].

In addition to the Nobel Prize, Rita Levi-Montalcini has received many honors and awards. In 1963, she was the first woman scientist to receive the Max Weinstein Award, given by the United Cerebral Palsy Association for outstanding contributions in neurological research. In 1975, Levi-Montalcini became the first woman to be installed in the Pontifical Scientific Academy. She is a recipient of the International Feltrinelli Medical Award of the Accademia Nazionale dei Lincei, Rome (1969), the William Thomson Wakeman Award of the National Paraplegia Foundation (1974), the Lewis S. Rosentiel Award for Distinguished work in Basic Medical Research of Brandeis University (1982), the Louisa Gross Horwitz Prize of Columbia University (1983), the Albert Lasker Basic Medical Research Award (1986), and the National Medal of Science (1987). She was a member of the American Academy of Arts and Sciences, the National Academy of Sciences, and the National Academy of Sciences of Italy. In 1999, the Food and Agriculture Organization of the United Nations named Rita Levi-Montalcini one of its first four FAO Ambassadors, to help in its campaign against world hunger.

\section{Humanitarian and civil involvements}

Unlike other people, Rita Levi-Montalcini was a complete human being. She had a high profile in civic involvement participating in the Committee of Science for Peace. In 1992, with her sister Paola, established a Foundation dedicated to improve the instructions for African women. On 1 August 2001, she was appointed as Senator for Life by the then President of the Italian Republic, Carlo Azeglio Ciampi.

In many occasion, she actively participated in the Italian political debate, mainly regarding ethical problems like the freedom of research, including those on embryo and stem cells, on the regulation of end of life and on autodetermination of the patients for the end of life.
"It is imperfection-not perfection-that is the end result of the program written into that formidably complex engine that is the human brain," Dr. Levi-Montalcini wrote in her autobiography, "and of the influences exerted upon us by the environment and whoever takes care of us during the long years of our physical, psychological and intellectual development."

Rita Levi-Montalcini died in her home in Rome 30 December 2012 at the age of 103.

The results of her scientific and humanitarian involvement, of her researches, of her books (La clessidra della vita, in which she describes her life dedicated to science and knowledge, L' asso nella manica a brandelli, dedicated to aging and its problems. Cronologia di una scoperta, in which describes the history of the discovery of NGF, Elogio dell' imperfezione, that is a tribute to the imperfection as a fundamental component of evolution, and Senz' olio contro vento that describes some personalities she met and who, with their life experience, are example for all) and her global history give immortality to this great lady.

For all these reasons, Italian Neurology and this journal says: "Thank you again, Rita!"

\section{References}

1. Les Prix Nobel (1987) The Nobel Prizes 1986. Editor Wilhelm Odelberg [Nobel Foundation], Stockholm

2. Abbott A (2009) Neuroscience: one hundred years of Rita. Nature 458(7238):564-567

3. Aloe L (2011) Rita Levi-Montalcini and the discovery of NGF, the first nerve cell growth factor. Arch Ital Biol 149(2):175-181

4. Chao MV (2010) A conversation with Rita Levi-Montalcini. Annu Rev Physiol 72:1-13

5. Cowan WM (2001) Viktor Hamburger and Rita Levi-Montalcini: the path to the discovery of nerve growth factor. Annu Rev Neurosci 24:551-600

6. Levi-Montalcini R (2000) From a home-made laboratory to the Nobel Prize: an interview with Rita Levi Montalcini. Int J Dev Biol 44(6):563-566 